\title{
MARCKS and MARCKS-like proteins in development and regeneration
}

\author{
Mohamed El Amri ${ }^{1}$, Una Fitzgerald ${ }^{2}$ and Gerhard Schlosser ${ }^{1,3^{*}}$ (D)
}

\begin{abstract}
Background: The Myristoylated Alanine-Rich C-kinase Substrate (MARCKS) and MARCKS-like protein 1 (MARCKSL1) have a wide range of functions, ranging from roles in embryonic development to adult brain plasticity and the inflammatory response. Recently, both proteins have also been identified as important players in regeneration. Upon phosphorylation by protein kinase C (PKC) or calcium-dependent calmodulin-binding, MARCKS and MARCKSL1 translocate from the membrane into the cytosol, modulating cytoskeletal actin dynamics and vesicular trafficking and activating various signal transduction pathways. As a consequence, the two proteins are involved in the regulation of cell migration, secretion, proliferation and differentiation in many different tissues.

Main body: Throughout vertebrate development, MARCKS and MARCKSL1 are widely expressed in tissues derived from all germ layers, with particularly strong expression in the nervous system. They have been implicated in the regulation of gastrulation, myogenesis, brain development, and other developmental processes. Mice carrying loss of function mutations in either Marcks or Marcks/1 genes die shortly after birth due to multiple deficiencies including detrimental neural tube closure defects. In adult vertebrates, MARCKS and MARCKL1 continue to be important for multiple regenerative processes including peripheral nerve, appendage, and tail regeneration, making them promising targets for regenerative medicine.

Conclusion: This review briefly summarizes the molecular interactions and cellular functions of MARCKS and MARCKSL1 proteins and outlines their vital roles in development and regeneration.
\end{abstract}

Keywords: MARCKS, MARCKS-like protein, Development, Regeneration, Cell migration

\section{Background}

The Myristoylated Alanine Rich C-Kinase Substrate (MARCKS) is a ubiquitous, highly conserved protein among vertebrates, which is essential for postnatal survival [1], and has been widely studied for its functions in the brain and nervous system. Being highly expressed in nervous tissue, particularly during early development but persisting in the adult, it plays numerous roles related to brain growth, neuronal migration, neurite outgrowth, neurotransmitter release, and synaptic plasticity (reviewed in [2]). In addition, the protein has been implicated in the

\footnotetext{
* Correspondence: gerhard.schlosser@nuigalway.ie

'Centre for Research in Medical Devices (CÚRAM), National University of Ireland, Galway, Biomedical Sciences Building, Newcastle Road, Galway, Ireland

${ }^{3}$ School of Natural Sciences and Regenerative Medicine Institute (REMEDI), National University of Ireland, Galway, Biomedical Sciences Building, Newcastle Road, Galway, Ireland

Full list of author information is available at the end of the article
}

regulation of other developmental events, including gastrulation [3], myogenesis [4], and vasculogenesis [5].

MARCKS protein has become established as a key regulator of many molecular interactions, such as those involving the dynamic actin cytoskeleton or membrane phosphoinositides (reviewed in [2, 6-8]). Many of the molecular characteristics of MARCKS are also shared by MARCKS-related proteins, including proteins with significant homology in the effector domain such as MARCKS-like protein 1 (MARCKSL1) and other proteins that have similar biochemical functions and localisation patterns, such as growth associated protein 43 (GAP43) and cytoskeletal-associated protein 23 (CAP23) [9]. Whereas GAP43 and CAP23 have long been shown to play important roles in neural regeneration [10, 11], only recently have MARCKS and MARCKSL1 been implicated in regeneration of neural and other tissues [12-14]. This review focuses on the emerging roles of MARCKS and MARCKS-like proteins in development

(c) The Author(s). 2018 Open Access This article is distributed under the terms of the Creative Commons Attribution 4.0 International License (http://creativecommons.org/licenses/by/4.0/), which permits unrestricted use, distribution, and 
and regeneration and explores possible mechanisms underlying their function.

\section{Main text}

Domain structures and molecular properties

MARCKS is an abundant, rod-shaped protein of $35 \mathrm{kDa}$ [15], with three highly conserved functional domains [2, 16] (Fig. 1a). In the centre of the protein, the effector domain (ED) is rich in positively charged lysine residues, while multiple serine residues make it susceptible to phosphorylation by protein kinase $\mathrm{C}$ (PKC), or other protein kinases such as Rho kinase (ROCK) $[2,15,17,18]$. Adjacent to the ED are two highly conserved regions. The first is the MARCKS Homology 2 (MH2) domain [19]. The second conserved region is the $\mathrm{N}$-terminal domain containing a myristoylation site, which undergoes a reversible co-translational attachment of myristic acid to its $\mathrm{N}$-terminal glycine residue [20]. In its non-phosphorylated state, the positively-charged ED attaches to the negatively charged cytosolic face of the plasma membrane [2] (Fig. 1b). As a result, the $\mathrm{N}$-terminal myristoylation site reversibly inserts into the plasma membrane, serving as a lipid anchor for the protein [21, 22]. Once the ED is phosphorylated, it loses its affinity for the plasma membrane, shifting MARCKS back into the cytoplasm [2] (Fig. 1b). This translocation, termed the 'electrostatic switch' [22], can also be achieved through increased $\mathrm{Ca}^{2+}$ levels, which enable calmodulin to bind to the ED of MARCKS [23] (Fig. 1b).

MARCKS-like protein 1 (MARCKSL1), also known as MARCKS-like protein (MLP), MARCKS-related protein (MRP), Brain Protein F52, or MacMARCKS, shares strong homology and functionality with MARCKS [24]. The $20 \mathrm{kDa}$ protein has a very similar ED to that of MARCKS, which also binds F-actin, $\mathrm{Ca}^{2+} /$ calmodulin, and acidic phospholipids. In addition, MARCKSL1 contains the same N-terminal myristoylation consensus sequence found in MARCKS [25]. However, it is important to note that MARCKSL1 has a lower alanine content than MARCKS, resulting in potential functional differences, and a distinct distribution pattern in the brain [24].

Depending on their phosphorylation state, MARCKS or MARCKSL1 have been shown to engage in a number of different molecular interactions. First, when the ED of
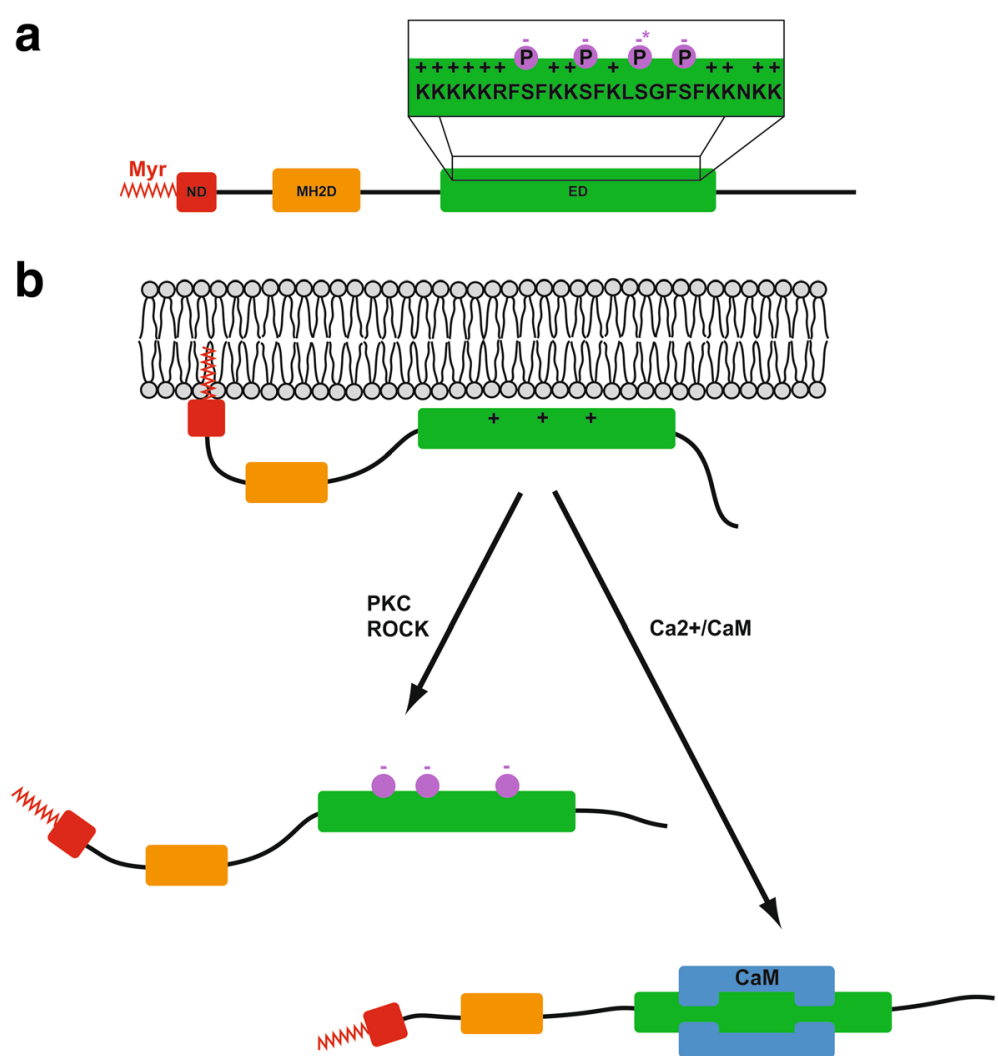

Fig. 1 MARCKS protein structure and electrostatic switch. a MARCKS protein has three protein domains, the N-Terminal domain (ND), which can be myristoylated (Myr), an MH2 domain (MH2D) and an effector domain (ED). The ED (amino acids 152-176 in human MARCKS) is magnified in the inset showing that it is highly positively charged and has 4 potential phosphorylation sites, one of which (asterisk) is poorly phosphorylated. b In the unphosphorylated state and in the absence of Calcium-calmodulin (CaM) binding, MARCKS is tethered to the membrane but becomes released into the cytosol when phosphorylated by protein kinase C (PKC) or Rho kinase (ROCK) or after Calcium-CaM binding. Modified from [8] 
MARCKS is unphosphorylated and attached to the plasma membrane, it achieves cross-linking of actin filaments by directly binding to filamentous (F) actin [26, 27] (Fig. 2a). In addition, MARCKS can promote the polymerisation of actin [28]. In a similar way, MARCKSL1 bundles and stabilises F-actin upon phosphorylation, increasing filopodium dynamics [29]. These direct interactions with the cytoskeleton have been implicated in the regulation of cell migration in various developmental contexts (see below) as well as in the regulation of mucin secretion in the human bronchial epithelium. The latter process, which is dysregulated in asthma and other respiratory diseases, involves the dephosphorylation of cytoplasmic MARCKS, promoting its interaction with both $\mathrm{F}$-actin and membrane bound proteins of secretory vesicles and resulting in increased mucin secretion [30, 31].

The electrostatic switch mechanism of MARCKS and MARCKSL1 also has important consequences for their ability to interact with phosphatidylinositol 4,5bisphosphate $\left(\mathrm{PIP}_{2}\right)[7,32,33] . \mathrm{PIP}_{2}$ is a membrane component, with numerous cellular functions, including second messenger generation and membraneanchoring of various proteins, including kinases and proteins with MARCKS-like domains [34, 35]. $\mathrm{PIP}_{2}$ is either selectively hydrolysed by phospholipase $\mathrm{C}$ (PLC), producing inositol triphosphate $\left(\mathrm{IP}_{3}\right)$ and diacylglycerol (DAG) [36], or is further phosphorylated by phosphoinositide 3-kinase (PI3K) to form $\mathrm{PIP}_{3}$. These three products act as second messengers in many eukaryotic signal transduction cascades. For example, DAG activates several PKC isozymes, stimulating the phosphorylation of select proteins by PKC. On the other hand, $\mathrm{IP}_{3}$ regulates the cytoplasmic concentration of $\mathrm{Ca}^{2+}$ by gating a $\mathrm{Ca}^{2+}$ channel in the endoplasmic reticulum. Furthermore, $\mathrm{IP}_{3}$ functions as a rate-limiting substrate in the synthesis of additional inositol polyphosphates, which can stimulate various protein kinases, transcription,

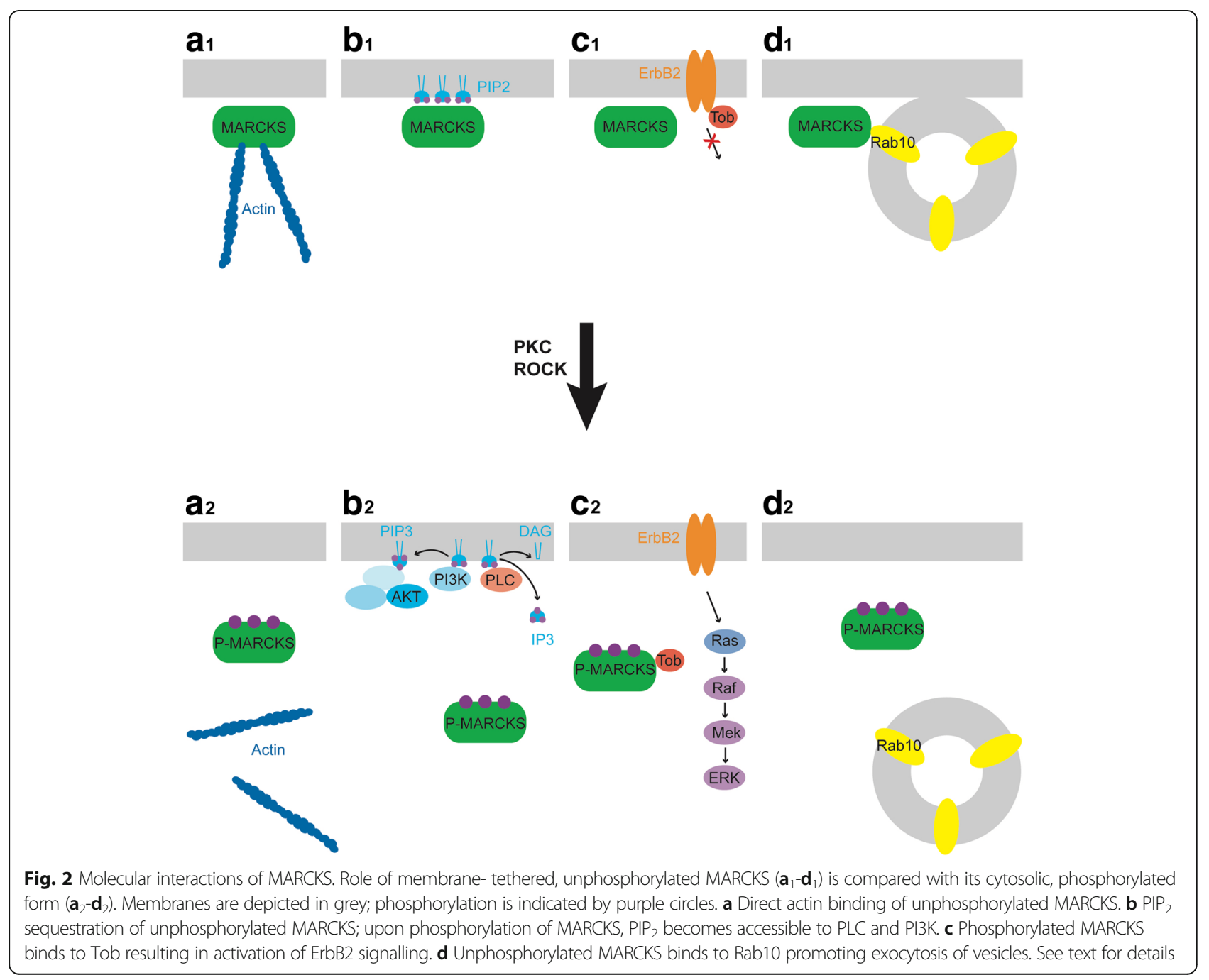


and mRNA processing events [36-38]. $\mathrm{PIP}_{3}$, finally, is involved in activating the AKT signalling pathway with a plethora of diverse functions [39].

It has been recurrently shown that membrane-bound MARCKS can isolate and sequester $\mathrm{PIP}_{2}$ within specific membrane micro-domains, or "lipid rafts", for participation in later signal transduction events, suggesting that it can modulate $\mathrm{PIP}_{2}$-dependent cellular processes by controlling the spatial availability of the phospholipid for enzymes such as PLC and PI3K [34, 40-42] (Fig. 2b). While $\mathrm{PIP}_{2}$ is critical for the activity and localisation of several membrane associated proteins, including focal adhesion kinase (FAK) $[34,35]$ many of the $\mathrm{PIP}_{2^{-}}$ dependent processes that MARCKS modulates remain currently unknown. However, $\mathrm{PIP}_{2}$ sequestration by MARCKS and related proteins has been shown to promote axon outgrowth [43]. While the mechanism is not completely resolved, it has been proposed that unmasked $\mathrm{PIP}_{2}$ interacts with and inhibits proteins promoting actin dynamics (e.g. gelsolin, cofilin, profilin), thereby indirectly stabilizing the cortical actin cytoskeleton. After sequestration of $\mathrm{PIP}_{2}$ by MARCKS, these proteins are released and now promote cell motility [43].

A further $\mathrm{PIP}_{2}$-dependent process that is affected by MARCKS is the activation of phospholipase D (PLD) $[7,44,45]$, which is involved in cytoskeletal actin dynamics, membrane trafficking, cell migration, and mitosis [46-51]. Since PIP 2 is required for PLD activation, it has been proposed that MARCKS-mediated PLD activation results from the phosphorylation-induced release of $\mathrm{PIP}_{2}$ [7]. PLD acts by hydrolysing phosphatidylcholine (PC), producing choline and phosphatidic acid (PA), which serve as second messengers in many signal transduction cascades [52, 53]. For instance, PA is known to play a significant role in actin stress fibre formation [54, 55], vesicular trafficking [56], cell proliferation $[57,58]$, neurite outgrowth [59], and MAP-kinase activation [60]. In addition, PA can also be converted into DAG and lysophosphatidic acid (LPA) [61], a potent signalling molecule with functions such as neurite retraction [62] and cell proliferation [63].

In addition to its $\mathrm{PIP}_{2}$-dependent modulation of various signalling pathways, MARCKS affects other signalling pathways by different mechanisms. As an example, following phosphorylation by PKC, MARCKS activates an ErbB2-mediated signal pathway, by binding to the anti-proliferative negative cell-cycle regulator Transducer of ErbB2 (TOB2), thereby decreasing its affinity to ErbB2 [64] (Fig. 2c). This in turn, promotes cell proliferation and maintenance of normal radial glial identity [65]. In addition, the exogenous overexpression of ErbB2 induces mature astrocytes to become radial glial progenitors in the adult mouse brain, promoting both neurogenesis and targeted neuronal migration
[66]. Furthermore, MARCKS has been associated with polysialic acid (PSA), which influences neural differentiation, migration [67] and axonal commissure formation [68-70]. When PSA is added to neural cell adhesion molecules (NCAMs) as a post-translational modification, it co-localises with MARCKS in the plasma membrane, stimulating neurite outgrowth [71]. Moreover, MARCKS has recently been shown to modulate Netrin-1 - Deleted in Colorectal Cancer (DCC) signalling by disrupting the localisation patterns of two of its subcellular mediators, protooncogene tyrosine-kinase SRC and FAK. As a result, axonal navigation in the corpus callosum becomes aberrant during a crucial phase of mouse brain development [72].

The apical localisation of MARCKS in ependymal and radial glial cells $[73,74]$ and the displacement of cellpolarity proteins such as aPKC, PAR3, CDC42, as well as $\beta$-catenin, prominin, and N-cadherin in $\mathrm{Marcks}^{-/}$ mouse embryos [73], suggest that MARCKS is also able to interact with membrane-associated proteins related to cell polarity and anchor them apically, although evidence for direct protein-protein interactions is currently lacking. However, radial glial cell polarity is perturbed in Marcks ${ }^{-/-}$embryos, resulting in reduced proliferation, changes in the proportion of asymmetric cell divisions, and displacement of radial glia cells, which can act both as neural progenitor cells and as pro-migratory scaffolds for neurons in the developing cortex [2, 73]. In addition, MARCKS may also affect cell polarity via $\mathrm{PIP}_{2}$ dependent mechanisms [73, 75-77].

Finally, MARCKS has been shown to interact with various vesicular proteins. Direct interactions with Rab10 in plasmalemmal precursor vesicles (PPVs) provide membranes to outgrowing axons when the ED is not phosphorylated [78] (Fig. 2d). Interactions with other vesicle associated proteins such as synapsin [79] or various chaperones [31] have been described and may contribute to the role of MARCKS for secretion of mucin, neurotransmitters, as well as inflammatory cytokines [31, 80-83]. MARCKS probably affects secretion by several distinct mechanisms, since the unphosphorylated form of the protein promotes mucin secretion [30, 31], while the phosphorylated form promotes neurotransmitter release and gut peptide secretion [80, 81].

In summary, MARCKS interacts with numerous molecular pathways. Much less is known about MARCKSL1, but the overall consequences of its interactions appear to be similar to MARCKS. Most notably, MARCKS affects cytoskeletal rearrangements, various signalling pathways, and vesicular trafficking. As a consequence, the protein affects predominantly cellular processes relying on these pathways during development or in the adult such as cell migration, secretion and phagocytosis, and cell proliferation and differentiation. Cell migration is affected not only by MARCKS' capacity 
for direct actin binding but also by multiple downstream effects of $\mathrm{PIP}_{2}$ sequestration $[26,27,43,44]$. Secretion and phagocytosis likewise appear to be modulated by several MARCKS interacting factors $[31,78,79]$. Finally, cell proliferation and differentiation are modulated by MARCKS' interaction with various signalling pathways, as well as possibly its interactions with cell polarity proteins $[64,73,84]$.

A large body of evidence indicates that the electrostatic switch mechanism between membrane bound (unphosphorylated) and cytosolic (phosphorylated or CaM-bound) MARCKS plays a crucial role in the regulation of each of these processes. However, there is conflicting evidence for the precise role of membrane bound versus cytosolic MARCKS. As discussed above, secretion appears to be promoted by unphosphorylated, membrane bound MARCKS in some contexts [30, 31] but by phosphorylated, cytosolic MARCKS in other contexts [80, 81]. Similarly, unphosphorylated, membrane bound MARCKS or MARCKSL1 have been shown to promote lamellipodium formation, axon outgrowth and cell motility in neurons and cancer cells in some studies [29, 43, 85-87], whereas phosphorylated, cytosolic MARCKS has been shown to promote cell motility in other studies [88-92]. Moreover, neither phosphorylation of the ED nor myristoylation of MARCKS are necessary for normal gross brain morphology in a transgenic line of mice overexpressing MARCKS [93-95], whereas myristoylation, but not phosphorylation, of MARCKS is required for radial glial polarity and localisation [73].

While some of these apparently paradoxical findings may be due to context-dependent interactions of MARCKS with different binding partners, others may reflect the dynamic requirement of both phosphorylated and unphosphorylated forms of MARCKS. Indeed, phosphorylation of MARCKS in migrating muscle precursors and neutrophils has been shown to be transient, followed by rapid dephosphorylation. While the phosphorylated form permits initial adhesion, the dephosphorylated form of MARCKS supports later stages of cell spreading [96, 97].

\section{Role of MARCKS and MARCKSL1 in development}

MARCKS and MARCKSL1 are expressed almost ubiquitously during vertebrate development, from early developmental stages and onwards, although there are some differences in MARCKS and MARCKSL1 expression patterns between species, developmental stages, tissues, and the phosphorylation state of the proteins. MARCKS and MARCKSL1 mRNA were shown to be maternally supplied in anamniotes and continue to be expressed throughout cleavage and gastrulation [16, 98, 99]. After neurulation, expression of MARCKS and MARCKSL1 is upregulated in the central (CNS) and peripheral nervous system (PNS) of all vertebrates, but continues to be expressed in many mesodermal and endodermal tissues [16, 24, 98-102]. During embryonic development of the CNS, MARCKS is first upregulated in the neuroepithelial cells of the emergent neural tube [100], before localising into the apical membranes of ventricular-zone neural progenitor cells (NPCs) $[73,103]$. Subsequently, it is found particularly enriched in axons and dendrites [104, 105].

The nearly ubiquitous expression pattern of MARCKS and MARCKSL1 suggests that they play a vital role during vertebrate development and this is supported by many functional studies. For example, five geneknockout studies in mice have shown that MARCKS and MARCKSL1 are both required for embryogenesis $[1,24,100,106,107]$. According to these reports, the absence of MARCKS and MARCKSL1 interfered with neural tube closure, leading to spina bifida and exencephaly, which resulted in perinatal lethality [108]. In addition, the disruption of the Marcks gene led to severe neuromuscular defects and decreased body size in mice $[1,73,93,100]$. Other neural embryonic defects included agenesis of forebrain commissures (e.g. the corpus callosum), neuronal ectopia, and abnormal retinal/cortical laminations $[1,100]$.

Additional functional studies in frog and zebrafish have shown that MARCKS plays an important role during early embryonic events such as gastrulation [3]. For example, by blocking MARCKS protein synthesis in Xenopus embryos using antisense morpholino oligonucleotides (MO), Ioka et al. reported impaired convergent extension movements due to cytoskeletal deregulation [3]. In zebrafish embryos, blocking the two MARCKS paralogs marcksa and marksb also resulted in gross phenotypic defects, including severely curved and truncated tails, gill-formation abnormalities, skeletal muscle deformities, and an abnormal brain architecture [16].

The neural abnormalities observed in MARCKS mutants strongly suggest that MARCKS has multiple roles in the developing nervous system. For example, it maintains normal radial glial cell polarity and cell adhesion in the neocortex during brain development [73]. Since mice with mutant non-myristoylatable MARCKS [94] were only partially rescued from severe cranial defects and perinatal death in comparison with mice lacking MARCKS PKC-phosphorylation sites [109], it can be speculated that the function of radial glial cells depends on MARCKS myristoylation rather than phosphorylation [73]. Similarly, in another study, a phosphorylation deficient mutant form of MARCKS protein was able to rescue CNS defects observed in Marcks $^{-/-}$knockout mice, suggesting that phosphorylation of MARCKS is not essential for CNS development [93]. 
However, another study suggests that the phosphorylation status of MARCKS plays a significant role in spinal cord development. In this study, Garrett et al. conditionally blocked the $\gamma$-Protocadherin allele Pcdh- $\gamma$, creating high levels of PKC that phosphorylated MARCKS [110]. As a result, dendrite complexity and arborisation were drastically reduced, having severe implications on CNS development. To confirm these results, dendrite abnormalities were rescued by blocking PKC, PLC, and FAK, the latter of which binds to $\gamma$-Protocadherins.

Moreover, MARCKS has been implicated in the regulation of neuronal migration and axon outgrowth during PNS and CNS development by modulating growth cone adhesion $[85,111]$ and the dynamics of the actin cytoskeleton $[29,43]$. The latter results in the stimulation of lamellipodia formation and neurite outgrowth by dephosphorylated MARCKS [29, 86, 112].

MARCKS and MARCKSL1 are also implicated in cell adhesion and migration of neural crest cells (NCCs). NCCs are a group of transient migratory cells that originate from the neural tube during embryogenesis and give rise to a variety of different cell types, including sensory neurons and glial cells of the PNS, cranial cartilage, and bone $[113,114]$. It has been suggested that migratingprecursor cells of the PNS that originate from NCCs express a significantly higher amount of MARCKS in chick embryos [102]. In addition, mice lacking MARCKSL1 have been shown to have impaired NCC migration, contributing to severe abnormalities including exencephaly and neural-tube defects [107]. For future experiments, it would be interesting to trace the behaviour and fate of MARCKS and MARCKSL1 in NCCs using cell-adhesion and cell-migration assays to further elucidate their role in development and regeneration.

In addition, MARCKS and MARCKSL1 are also involved in modulating migration during development of many other tissues. For example, by reversibly blocking MARCKS-translocation and myoblast-fusion in chick embryos, Kim et al. found that PKC-controlled MARCKS translocation is a prerequisite for myoblast fusion, a key cellular event that shapes the formation, fusion, and repair of embryonic muscle cells $[4,109,115]$. Moreover, MARCKS regulates vascular endothelial cell migration by influencing insulin-dependent signalling to $\mathrm{PIP}_{2}$, which in turn affects actin assembly and cellular development in the vascular endothelium [5]. MARCKS has also been shown to play a critical role in angiotensin-II signalling, which directly influences endothelial cell motility [116].

As a whole, the role of MARCKS in cell migration, secretion, proliferation and differentiation appears common to a diverse array of developmental functions, and continues to be important in several adult tissues. For example, as discussed above, adult MARCKS plays an important role in mucin secretion in the airways [30]. Moreover, in the mature nervous system, MARCKS and MARCKSL1 serve a variety of functions, including the promotion of neurotransmitter release and gut peptide secretion $[80,81]$, as well as a role in synaptic plasticity and learning and memory, possibly due to their ability to promote dendritic spine maintenance $[2,105,117]$. In addition, MARCKS and MARCKSL1 play important roles in the immune system, where they promote migration of inflammatory cells and the secretion of cytokines as discussed in more detail below. Dysregulation of MARCKS or MARCKSL1 has also been implicated in many different cancers, where they affect tumorigenesis, metastasis and angiogenesis $[8,118]$.

\section{Role of MARCKS and MARCKSL1 in regeneration}

There is strong evidence for a role of the proteins GAP43 and CAP23 in regeneration in both the PNS and CNS [10, 11, 119-123]. These two proteins are structurally and mechanistically related PKC substrates that share numerous functions including $\mathrm{PIP}_{2^{-}}$and- actin cytoskeletal regulation with MARCKS [9, 43, 124]. Based on these similarities, the trio of GAP43, MARCKS and CAP23 is commonly referred to as GMC proteins.

For example, GAP43 and CAP23 are highly expressed in mouse motor nerves during regeneration $[120,125]$ and play a critical role in regulating nerve sprouting $[124,126]$. They have also been implicated in the regeneration of axons in the dorsal root ganglia and sciatic nerves [43, 127], olfactory epithelia [128], retinal ganglion cells [129], and the cerebral cortex [130]. Coexpression of these two proteins triggers a 60 -fold increase in dorsal root ganglion axon regeneration after spinal cord injury in mice [131]. In the cerebellum, overexpression of GAP43 induces axonal sprouting [132, 133], while downregulation of GAP43 by RNAi interferes with axonal regrowth after injury [134].

In contrast to other GMC proteins, MARCKS and MARCKSL1 have only recently emerged as potentially important players during the regenerative process. In 2000, McNamara et al. showed that MARCKS expression, like GAP43, is significantly upregulated in regenerating neurons after facial axonal lesions in rats [12]. Both proteins are also highly expressed during neurite outgrowth of dorsal root ganglia and superior cervical ganglia [123]. Furthermore, MARCKS is highly upregulated during optic nerve regeneration [135] and during axonal sprouting after brain stroke [126], suggesting that MARCKS, like GAP43 and CAP23, may play an important role in axon outgrowth during regeneration in both PNS and CNS, although disappointingly, functional studies confirming this are still lacking. Outside of the nervous system, MARCKS has also been shown to be upregulated during lens regeneration [136] and during 
cardiac tissue regeneration following infarction [137], while MARCKSL1 is elevated during lungfish fin regeneration [14]. Using qPCR analysis on the fin blastema, a collection of relatively undifferentiated and proliferating cells capable of regeneration, it was shown that lungfish Marcksl1 reaches its highest level of expression 1 day post amputation, returning to basal levels at 3 weeks post-amputation [14].

A recent publication by Sugiura et al. now suggests a different and more pervasive role for MARCKSL1 in regeneration, by demonstrating that extracellularly released axolotl MARCKS-like protein (AxMLP) is responsible for inducing the early proliferative response in axolotl tail and limb regeneration [13]. Using a variety of experimental strategies, these researchers identified AxMLP as an extracellular factor that is strongly associated with cell proliferation and blastemal length. For instance, in-vivo knock-down studies revealed that AxMLP is necessary for the elevated levels of cell proliferation following injury, while immunohistochemical analysis of AxMLP distribution in epidermal and spinal cord tissues showed that the protein is mostly cytoplasmic in uninjured tissue, before translocating to the membrane following injury in accordance with its proposed extracellular secretion.

Today, the mechanisms of AxMLP extracellular release remain currently unknown. Confirmation and elucidation of the mode of MARCKSL1 secretion promises to provide novel insights into unconventional protein secretion mechanisms since it does not contain a signal peptide. In addition, secretion of MARCKS or MARCKSL1 so far has only been reported in the highly regenerative axolotl but has not been found in other vertebrates, raising the possibility that secretion of these proteins may be linked to their ability to promote regeneration.

Taken together with previous observations, this study suggests that MARCKS and MARCKSL1 play important roles during regeneration. While the underlying molecular mechanisms are still unresolved, insights from molecular and developmental studies suggest some candidate pathways, which will be discussed in the following sections. As summarized above, MARCKS and MARCKSL1 have important roles in the development of multiple tissues, but they have also been shown to be important in the inflammatory response to injury. This suggests that MARCKS and MARCKSL1 may potentially affect the regenerative response in two very different but not mutually exclusive ways. First, by promoting the regenerative process in the injured tissue itself and second, by modulating the inflammatory response.

\section{Potential direct roles in the injured tissue}

The first response to limb- or tail amputation in species capable of regeneration is the formation of a blastema, involving the migration of cells, followed by cell-cycle re-entry and blastemal-cell proliferation. These cellular mechanisms, including migration, proliferation, and differentiation, are known to be conserved amongst most species after injury [138]. MARCKS and MARCKSL1 have been implicated in many of the processes underlying blastema formation, suggesting that they may play multiple roles during this process. First, MARCKS has been shown to promote proliferation, by activating the ErbB2-mediated signal pathway or by interacting with cell polarity proteins $[64,73]$. As mentioned previously, ErbB2 overexpression has also been shown to induce astrocytes to dedifferentiate and revert to a progenitor state [66] and similar processes would be required during blastema formation.

Second, MARCKS has been shown to induce cellular migration, which is another critical component of regeneration [139-141]. As discussed above, MARCKS influences cell migration by a multitude of mechanisms, including its interactions with actin, $\mathrm{PIP}_{2}$ sequestration, and the activation of various signalling pathways. In addition, MARCKS has been shown to mediate the effects of the noncanonical Wnt pathway on cortical actin dynamics during the formation of lamellipodia- and filopodia-like protrusions [3]. This pathway has been shown to promote regeneration in Xenopus and zebrafish, and is necessary for axolotl appendage regeneration [142]. The established role of MARCKS in promoting axon outgrowth via its effect on cell adhesion and actin dynamics may also contribute to neural regeneration.

\section{Potential indirect roles in modulating inflammation}

The process of inflammation also plays a critical role in the regeneration of injured tissue through a variety of highly conserved pathways. Although severe inflammation typically inhibits regeneration, a moderate and wellregulated inflammatory response may actually be required for the initiation of regeneration [143-145]. Depending on the injury site and organism, cells such as macrophages and neutrophils that infiltrate the wound and secrete cytokines are characteristic of the inflammatory response [139, 144, 146-150]. Macrophages, which are necessary for salamander limb regeneration [151, 152], are known to functionally depend on MARCKS and MARCKSL1.

The importance of MARCKS and MARCKSL1 in inflammation is well established. MARCKSL1 was initially termed 'MacMARCKS' due to its high level of expression in macrophages [153], and up to date, numerous studies have associated MARCKS and MARCKSL1 with normal macrophage function [154, 155]. For instance, both MARCKS and MARCKSL1 are implicated in macrophage transmigration [156] through a process involving phosphorylation, actin binding, and cytosol translocation [90]. During the inflammatory response, MARCKS has also been shown to act as a major 
regulator of human neutrophil migration and adhesion [88], also promoting neutrophil secretion of inflammatory cytokines [82, 83, 157, 158].

Finally, MARCKS upregulation is associated with microglial activation and neuroinflammation after CNS injuries [159]. Interestingly, although the mechanisms of microglial activation during axonal regeneration remain disputable [160, 161], studies suggest that amyloid beta might be responsible for promoting microglial activation by stimulating PKC and MAPK to phosphorylate MARCKS [162].

\section{Conclusions}

Over the past three decades, major advances in research have identified MARCKS and MARCKSL1 as key players during developmental and regenerative processes. These include brain, kidney, blood-vessel, and muscle development, as well as appendage regeneration. However, while numerous molecular interactions of MARCKS-related molecules, such as their interactions with the actin cytoskeleton and membrane phosphoinositides have been unravelled, their respective role for various developmental and regenerative processes is very poorly understood. Moreover, these multifaceted molecules probably contribute to development and regeneration by additional mechanisms which remain yet to be characterised.

For example, the phosphorylation-site domain (ED) in MARCKS is homologous to a region in diacylglycerol kinase zeta (DGKC), which has been shown to bind to and modulate the function of retinoblastoma protein $(\mathrm{Rb})$ [163-165]. Rb is implicated in cell cycle regulation and has been shown to be important for cell cycle re-entry of newt myotubes [166-168], but whether this function is MARCKS or MARCKSL1 dependent has not been investigated yet. The ED also acts as a nuclear localisation signal, suggesting that MARCKS may have unrecognized functions in the nucleus, including potential roles in the modulation of gene expression and of nuclear $\mathrm{PIP}_{2}$ localisation [169].

Retinoic acid (RA) is another factor which has been shown to affect MARCKS function in rat hippocampal cells, where it leads to its translocation from the membrane to the cytosol [170]. As a metabolite of vitamin A, RA plays a significant role in numerous regenerative processes such as nerve, auditory hair cell, fin/limb and lung regeneration [171-177], but whether any of these effects depend on MARCKS remains yet to be explored. Finally, the demonstration that AxMLP acts as a secreted factor in axolotl limb regeneration suggests additional and hitherto unknown modes of action.

Therefore, further research is required to assess the precise mechanisms by which MARCKS and MARCKSL1 contribute to development and regeneration, providing professionals with the molecular tools that will help them design new therapies for illnesses such as asthma, cancer, and spinal cord injury $[8,131,178]$.

\section{Abbreviations}

aPKC: Atypical protein kinase C; AxMLP: Axolotl MLP; CAP23: Cytoskeletal associated protein 23; DAG: Diacylglycerol; DGKZ: Diacylglycerol kinase zeta; ED: Effector domain; FAK: Focal adhesion kinase; GAP43: Growth associated protein 43; hpa: Hours post-amputation; IP3: Inositol triphosphate; LPA: Lysophosphatidic acid; MARCKS: Myristoylated alanine-rich C-kinase substrate; MARCKSL1: MARCKS-like 1; MH2: MARCKS homology 2; MLP: MARCKS-like protein; MO: Morpholino oligonucleotides; MRP: MARCKSrelated protein; NCAM: Neural cell adhesion molecule; NCCs: Neural crest cells; NPCs: Neural progenitor cells; PA: Phosphatidic acid; PAR3: Partitioning defective 3; PC: Phosphatidylcholine; PI3K: Phosphoinositide 3-kinase; $\mathrm{PIP}_{2}$ : Phosphatidylinositol 4,5-bisphosphate; PKC: Protein kinase C; PLC: Phospholipase C; PLD: Phospholipase D; PPVs: Plasmalemmal precursor vesicles; PSA: Polysialic acid; RA: Retinoic acid; Rb: Retinoblastoma protein; ROCK: Rho kinase; TOB2: Transducer of ErbB2

\section{Funding}

This work was supported in part by the Hardiman Research Scholarship from NUI Galway.

\section{Authors' contributions}

MEA and GS have written the manuscript and UF has contributed to its revision. All authors have made contributions to the conception and design of this review and have reviewed the manuscript.

Ethics approval and consent to participate

Not applicable

\section{Competing interests}

The authors declare that they have no competing interests.

\section{Publisher's Note}

Springer Nature remains neutral with regard to jurisdictional claims in published maps and institutional affiliations.

\section{Author details}

${ }^{1}$ Centre for Research in Medical Devices (CÚRAM), National University of Ireland, Galway, Biomedical Sciences Building, Newcastle Road, Galway, Ireland. ' Galway Neuroscience Centre, School of Natural Sciences, Biomedical Sciences Building, National University of Ireland, Newcastle Road, Galway, Ireland. ${ }^{3}$ School of Natural Sciences and Regenerative Medicine Institute (REMEDI), National University of Ireland, Galway, Biomedical Sciences Building, Newcastle Road, Galway, Ireland.

Received: 31 January 2018 Accepted: 7 May 2018

Published online: 22 May 2018

\section{References}

1. Stumpo DJ, Bock CB, Tuttle JS, Blackshear PJ. MARCKS deficiency in mice leads to abnormal brain development and perinatal death. Proc Natl Acad Sci U S A. 1995;92(4):944-8.

2. Brudvig JJ, Weimer JM. X MARCKS the spot: myristoylated alanine-rich C kinase substrate in neuronal function and disease. Front Cell Neurosci. 2015;9:407.

3. lioka H, Ueno N, Kinoshita N. Essential role of MARCKS in cortical actin dynamics during gastrulation movements. J Cell Biol. 2004;164(2):169-74.

4. Kim SS, Kim JH, Kim HS, Park DE, Chung CH. Involvement of the theta-type protein kinase $C$ in translocation of myristoylated alanine-rich $C$ kinase substrate (MARCKS) during myogenesis of chick embryonic myoblasts. Biochem J. 2000;347(Pt 1):139-46.

5. Kalwa $\mathrm{H}$, Michel T. The MARCKS protein plays a critical role in phosphatidylinositol 4,5-bisphosphate metabolism and directed cell movement in vascular endothelial cells. J Biol Chem. 2011;286(3):2320-30.

6. Arbuzova A, Schmitz AA, Vergeres G. Cross-talk unfolded: MARCKS proteins. Biochem J. 2002;362(Pt 1):1-12.

7. Sundaram M, Cook HW, Byers DM. The MARCKS family of phospholipid binding proteins: regulation of phospholipase D and other cellular components. Biochem Cell Biol. 2004;82(1):191-200.

8. Fong LWR, Yang DC, Chen C-H. Myristoylated alanine-rich C kinase substrate (MARCKS): a multirole signaling protein in cancers. Cancer Metastasis Rev. 2017;36(4):737-47. 
9. Wiederkehr A, Staple J, Caroni P. The motility-associated proteins GAP-43, MARCKS, and CAP-23 share unique targeting and surface activity-inducing properties. Exp Cell Res. 1997;236(1):103-16.

10. Skene JP. Axonal growth-associated proteins. Annu Rev Neurosci. 1989; 12(1):127-56.

11. Holahan MR. A shift from a pivotal to supporting role for the growthassociated protein (GAP-43) in the coordination of axonal structural and functional plasticity. Front Cell Neurosci. 2017;11:266.

12. McNamara $R$, Jiang $Y$, Streit $W$, Lenox R. Facial motor neuron regeneration induces a unique spatial and temporal pattern of myristoylated alanine-rich C kinase substrate expression. Neuroscience. 2000;97(3):581-9.

13. Sugiura T, Wang H, Barsacchi $R$, Simon A, Tanaka EM. MARCKS-like protein is an initiating molecule in axolotl appendage regeneration. Nature. 2016; 531(7593):237-40.

14. Nogueira AF, Costa CM, Lorena J, Moreira RN, Frota-Lima GN, Furtado C, Robinson M, Amemiya CT, Darnet S, Schneider I. Tetrapod limb and sarcopterygian fin regeneration share a core genetic programme. Nat Commun. 2016;7:13364

15. Ramsden JJ. MARCKS: a case of molecular exaptation? Int J Biochem Cell Biol. 2000;32(5):475-9.

16. Ott LE, McDowell ZT, Turner PM, Law JM, Adler KB, Yoder JA, Jones SL. Two myristoylated alanine-rich C-kinase substrate (MARCKS) paralogs are required for normal development in zebrafish. Anat Rec (Hoboken). 2011; 294(9):1511-24.

17. Ikenoya M, Hidaka H, Hosoya T, Suzuki M, Yamamoto N, Sasaki Y. Inhibition of rho-kinase-induced myristoylated alanine-rich C kinase substrate (MARCKS) phosphorylation in human neuronal cells by H-1152, a novel and specific rhokinase inhibitor. J Neurochem. 2002;81(1):9-16.

18. Nagumo H, Ikenoya M, Sakurada K, Furuya K, Ikuhara T, Hiraoka H, Sasaki Y. Rho-associated kinase phosphorylates MARCKS in human neuronal cells. Biochem Biophys Res Commun. 2001;280(3):605-9.

19. Toledo A, Zolessi FR, Arruti C. A novel effect of MARCKS phosphorylation by activated PKC: the dephosphorylation of its serine 25 in chick neuroblasts. PLoS One. 2013;8(4):e62863.

20. Manenti S, Sorokine O, Van Dorsselaer A, Taniguchi H. Demyristoylation of the major substrate of protein kinase C (MARCKS) by the cytoplasmic fraction of brain synaptosomes. J Biol Chem. 1994;269(11): 8309-13.

21. Kim J, Blackshear PJ, Johnson JD, McLaughlin S. Phosphorylation reverses the membrane association of peptides that correspond to the basic domains of MARCKS and neuromodulin. Biophys J. 1994;67(1):227-37.

22. McLaughlin S, Aderem A. The myristoyl-electrostatic switch: a modulator of reversible protein-membrane interactions. Trends Biochem Sci. 1995;20(7):272-6.

23. Kim J, Shishido T, Jiang X, Aderem A, McLaughlin S. Phosphorylation, high ionic strength, and calmodulin reverse the binding of MARCKS to phospholipid vesicles. J Biol Chem. 1994;269(45):28214-9.

24. Stumpo DJ, Eddy RL, Haley LL, Sait S, Shows TB, Lai WS, Young WS, Speer MC, Dehejia A, Polymeropoulos M. Promoter sequence, expression, and fine chromosomal mapping of the human gene (MLP) encoding the MARCKSlike protein: Identification of neighboring and linked polymorphic loci forMLPandMACSand use in the evaluation of human neural tube defects. Genomics. 1998:49(2):253-64.

25. Umekage T, Kato K. A mouse brain CDNA encodes a novel protein with the protein kinase $C$ phosphorylation site domain common to MARCKS. FEBS Lett. 1991;286(1-2):147-51.

26. Hartwig $\mathrm{JH}$, Thelen M, Rosen A, Janmey PA, Nairn AC, Aderem A. MARCKS is an actin filament crosslinking protein regulated by protein kinase $C$ and calcium-calmodulin. Nature. 1992;356(6370):618-22.

27. Yarmola EG, Edison AS, Lenox RH, Bubb MR. Actin filament cross-linking by MARCKS: characterization of two actin-binding sites within the phosphorylation site domain. J Biol Chem. 2001;276(25):22351-8.

28. Wohnsland F, Schmitz AA, Steinmetz MO, Aebi U, Vergères G. Interaction between actin and the effector peptide of MARCKS-related protein IDENTIFICATION OF FUNCTIONAL AMINO ACID SEGMENTS. J Biol Chem. 2000:275(27):20873-9.

29. Bjorkblom B, Padzik A, Mohammad H, Westerlund N, Komulainen E, Hollos P, Parviainen L, Papageorgiou AC, Iljin K, Kallioniemi O, Kallajoki M, Courtney MJ, Magard M, James P, Coffey ET. C-Jun N-terminal kinase phosphorylation of MARCKSL1 determines actin stability and migration in neurons and in cancer cells. Mol Cell Biol. 2012;32(17):3513-26.
30. Li Y, Martin LD, Spizz G, Adler KB. MARCKS protein is a key molecule regulating mucin secretion by human airway epithelial cells in vitro. J Bio Chem. 2001;276(44):40982-90.

31. Park J, Fang S, Crews AL, Lin KW, Adler KB. MARCKS regulation of mucin secretion by airway epithelium in vitro: interaction with chaperones. Am J Respir Cell Mol Biol. 2008;39(1):68-76.

32. Wang J, Arbuzova A, Hangyás-Mihályné G, McLaughlin S. The effector domain of myristoylated alanine-rich $C$ kinase substrate binds strongly to phosphatidylinositol 4, 5-bisphosphate. J Biol Chem. 2001;276(7): 5012-9.

33. Ziemba BP, Burke JE, Masson G, Williams RL, Falke JJ. Regulation of PI3K by PKC and MARCKS: single-molecule analysis of a reconstituted signaling pathway. Biophys J. 2016:110(8):1811-25.

34. McLaughlin S, Wang J, Gambhir A, Murray D. PIP2 and proteins: interactions, organization, and information flow. Annu Rev Biophys Biomol Struct. 2002;31(1):151-75

35. Goni GM, Epifano C, Boskovic J, Camacho-Artacho M, Zhou J, Bronowska A, Martin MT, Eck MJ, Kremer L, Grater F, Gervasio FL, Perez-Moreno M, Lietha D. Phosphatidylinositol 4,5-bisphosphate triggers activation of focal adhesion kinase by inducing clustering and conformational changes. Proc Natl Acad Sci U S A. 2014;111(31):E3177-86.

36. Essen LO, Perisic O, Katan M, Wu Y, Roberts MF, Williams RL. Structura mapping of the catalytic mechanism for a mammalian phosphoinositidespecific phospholipase C. Biochemistry. 1997;36(7):1704-18.

37. Suh PG, Park JI, Manzoli L, Cocco L, Peak JC, Katan M, Fukami K, Kataoka T, Yun S, Ryu SH. Multiple roles of phosphoinositide-specific phospholipase C isozymes. BMB Rep. 2008;41(6):415-34.

38. Kadamur G, Ross EM. Mammalian phospholipase C. Annu Rev Physiol. 2013;75:127-54

39. Manning BD, Toker AAKT. PKB signaling: navigating the network. Cell. 2017;169(3):381-405

40. Gambhir A, Hangyás-Mihályné G, Zaitseva I, Cafiso DS, Wang J, Murray D, Pentyala SN, Smith SO, McLaughlin S. Electrostatic sequestration of PIP2 on phospholipid membranes by basic/aromatic regions of proteins. Biophys J. 2004;86(4):2188-207.

41. McLaughlin S, Murray D. Plasma membrane phosphoinositide organization by protein electrostatics. Nature. 2005;438(7068):605.

42. Gamper N, Shapiro MS. Target-specific PIP2 signalling: how might it work? J Physiol. 2007:582(3):967-75

43. Laux T, Fukami K, Thelen M, Golub T, Frey D, Caroni P. GAP43, MARCKS, and CAP23 modulate PI(4,5)P(2) at plasmalemmal rafts, and regulate cell cortex actin dynamics through a common mechanism. J Cell Biol. 2000;149(7):1455-72.

44. Morash SC, Rose SD, Byers DM, Ridgway ND, Cook HW. Overexpression of myristoylated alanine-rich C-kinase substrate enhances activation of phospholipase D by protein kinase C in SK-N-MC human neuroblastoma cells. Biochem J. 1998:332(Pt 2):321-7.

45. Morash SC, Byers DM, Cook HW. Activation of phospholipase D by PKC and GTPYS in human neuroblastoma cells overexpressing MARCKS. Biochim. Biophys. Acta Mol. Cell Biol. Lipids. 2000;1487(2):177-89.

46. Cockcroft S, Phospholipase D. Regulation by GTPases and protein kinase C and physiological relevance. Prog Lipid Res. 1996;35(4):345-70.

47. Gomez-Cambronero J, Keire P, Phospholipase D. A novel major player in signal transduction. Cell Signal. 1998;10(6):387-97.

48. Frohman MA, Sung T-C, Morris AJ. Mammalian phospholipase D structure and regulation. Biochim. Biophys. Acta Mol. Cell Biol. Lipids. 1999;1439(2):175-86.

49. Exton J. Regulation of phospholipase D. Biochim. Biophys. Acta Mol. Cell Biol. Lipids. 1999;1439(2):121-33.

50. Exton JH. Regulation of phospholipase D. FEBS Lett. 2002;531(1):58-61.

51. Foster DA, Xu L. Phospholipase D in cell proliferation and Cancer11National Cancer institute, and the institutional support from the research centers in minority institutions (RCMI) program of the NIH. Mol Cancer Res. 2003;1(11): 789-800.

52. Brown HA, Thomas PG, Lindsley CW. Targeting phospholipase D in cancer, infection and neurodegenerative disorders. Nat Rev Drug Discov. 2017; 16(5):351

53. Selvy PE, Lavieri RR, Lindsley CW, Brown HA. Phospholipase D: enzymology, functionality, and chemical modulation. Chem Rev. 2011;111(10):6064-119.

54. Kam Y, Exton JH. Phospholipase $D$ activity is required for actin stress fiber formation in fibroblasts. Mol Cell Biol. 2001;21(12):4055-66. 
55. Cross MJ, Roberts S, Ridley AJ, Hodgkin MN, Stewart A, Claesson-Welsh L, Wakelam MJ. Stimulation of actin stress fibre formation mediated by activation of phospholipase D. Curr Biol. 1996;6(5):588-97.

56. Roth MG. Molecular mechanisms of PLD function in membrane traffic. Traffic. 2008;9(8):1233-9.

57. Joseph T, Bryant A, Frankel P, Wooden R, Kerkhoff E, Rapp UR, Foster DA Phospholipase D overcomes cell cycle arrest induced by high-intensity Raf signaling. Oncogene. 2002;21(22):3651.

58. Zhang W, Wang C, Qin C, Wood T, Olafsdottir G, Welti R, Wang X. The oleate-stimulated phospholipase D, PLDdelta, and phosphatidic acid decrease H2O2-induced cell death in Arabidopsis. Plant Cell. 2003;15(10): 2285-95.

59. Zhang Y, Huang P, Du G, Kanaho Y, Frohman MA, Tsirka SE. Increased expression of two phospholipase D isoforms during experimentally induced hippocampal mossy fiber outgrowth. Glia. 2004;46(1):74-83.

60. Rizzo MA, Shome K, Vasudevan C, Stolz DB, Sung T-C, Frohman MA, Watkins SC, Romero G. Phospholipase D and its product, phosphatidic acid, mediate agonist-dependent raf- 1 translocation to the plasma membrane and the activation of the mitogen-activated protein kinase pathway. J Biol Chem. 1999;274(2):1131-9.

61. Lin M-E, Herr DR, Chun J. Lysophosphatidic acid (LPA) receptors: signaling properties and disease relevance. Prostaglandins Other Lipid Mediat. 2010;91(3-4):130-8.

62. Nishizuka Y. Intracellular signaling by hydrolysis of phospholipids and activation of protein kinase C. Science. 1992;258(5082):607-14.

63. Moolenaar WH. Lysophosphatidic acid, a multifunctional phospholipid messenger. J Biol Chem. 1995;270(22):12949-52.

64. Cho SJ, La M-h, Ahn JK, Meadows GG, Joe CO. Tob-mediated cross-talk between MARCKS phosphorylation and ErbB-2 activation. Biochem Biophys Res Commun. 2001;283(2):273-7.

65. Anton E, Marchionni M, Lee K, Rakic P. Role of GGF/neuregulin signaling in interactions between migrating neurons and radial glia in the developing cerebral cortex. Development. 1997;124(18):3501-10.

66. Ghashghaei H, Weimer JM, Schmid RS, Yokota Y, McCarthy KD, Popko B, Anton E. Reinduction of ErbB2 in astrocytes promotes radial glial progenitor identity in adult cerebral cortex. Genes Dev. 2007;21(24):3258-71.

67. Angata K, Huckaby V, Ranscht B, Terskikh A, Marth JD, Fukuda M. Polysialic acid-directed migration and differentiation of neural precursors are essentia for mouse brain development. Mol Cell Biol. 2007;27(19):6659-68.

68. Zhang $\mathrm{H}$, Miller $\mathrm{RH}$, Rutishauser U. Polysialic acid is required for optimal growth of axons on a neuronal substrate. J Neurosci. 1992;12(8):3107-14.

69. Marx M, Rutishauser U, Bastmeyer M. Dual function of polysialic acid during zebrafish central nervous system development. Development. 2001;128(24): 4949-58.

70. Langhauser M, Ustinova J, Rivera-Milla E, Ivannikov D, Seidl C, Slomka C, Finne J, Yoshihara Y, Bastmeyer M, Bentrop J. Ncam1a and Ncam1b: two carriers of polysialic acid with different functions in the developing zebrafish nervous system. Glycobiology. 2011;22(2):196-209.

71. Theis T, Mishra B, von der Ohe M, Loers G, Prondzynski M, Pless O, Blackshear PJ, Schachner M, Kleene R. Functional role of the interaction between polysialic acid and myristoylated alanine-rich $C$ kinase substrate at the plasma membrane. J Biol Chem. 2013;288(9):6726-42.

72. Brudvig JJ, Cain JT, Schmidt-Grimminger GG, Stumpo DJ, Roux KJ, Blackshear PJ, Weimer JM. MARCKS is necessary for netrin-DCC signaling and Corpus callosum formation. Mol Neurobiol. 2018; https://doi.org/10. 1007/s12035-018-0990-3.

73. Weimer JM, Yokota Y, Stanco A, Stumpo DJ, Blackshear PJ, Anton ES. MARCKS modulates radial progenitor placement, proliferation and organization in the developing cerebral cortex. Development. 2009;136(17):2965-75.

74. Muthusamy N, Sommerville LJ, Moeser AJ, Stumpo DJ, Sannes P, Adler K, Blackshear PJ, Weimer JM, Ghashghaei HT. MARCKS-dependent mucin clearance and lipid metabolism in ependymal cells are required for maintenance of forebrain homeostasis during aging. Aging Cell. 2015;14(5): 764-73

75. Janetopoulos C, Devreotes P. Phosphoinositide signaling plays a key role in cytokinesis. J Cell Biol. 2006;174(4):485-90.

76. Marín-Vicente C, Nicolás FE, Gómez-Fernández JC, Corbalán-García S. The Ptdlns $(4,5)$ P2 ligand itself influences the localization of PKCa in the plasma membrane of intact living cells. J Mol Biol. 2008;377(4):1038-52.

77. Martin-Belmonte F, Mostov K. Phosphoinositides control epithelial development. Cell Cycle. 2007;6(16):1957-61.
78. Xu X-H, Deng C-Y, Liu Y, He M, Peng J, Wang T, Yuan L, Zheng Z-S, Blackshear PJ, Luo Z-G. MARCKS regulates membrane targeting of Rab10 vesicles to promote axon development. Cell Res. 2014;24(5):576.

79. Mizutani A, Tokumitsu H, Hidaka H. Acidic calmodulin binding protein, ACAMP-81, is MARCKS protein interacting with synapsin I. Biochem Biophys Res Commun. 1992;182(3):1395-401.

80. Li J, O'Connor KL, Greeley GH, Blackshear PJ, Townsend CM, Evers BM. Myristoylated alanine-rich $C$ kinase substrate-mediated neurotensin release via protein kinase $\mathrm{C}-\delta$ downstream of the rho/ROK pathway. J Biol Chem. 2005;280(9):8351-7.

81. Park J, Fang S, Adler KB. Regulation of airway mucin secretion by MARCKS protein involves the chaperones heat shock protein 70 and cysteine string protein. Proc Am Thorac Soc. 2006;3(6):493.

82. Takashi S, Park J, Fang S, Koyama S, Parikh I, Adler KBA. Peptide against the N-terminus of myristoylated alanine-rich $C$ kinase substrate inhibits degranulation of human leukocytes in vitro. Am J Respir Cell Mol Biol. 2006:34(6):647-52.

83. Damera G, Jester WF, Jiang M, Zhao H, Fogle HW, Mittelman M, Haczku A, Murphy E, Parikh I, Panettieri RA Jr. Inhibition of myristoylated alanine-rich C kinase substrate (MARCKS) protein inhibits ozone-induced airway neutrophilia and inflammation. Exp Lung Res. 2010;36(2):75-84.

84. Zhao J, Izumi T, Nunomura K, Satoh S, Watanabe S. MARCKS-like protein, a membrane protein identified for its expression in developing neural retina, plays a role in regulating retinal cell proliferation. Biochem J. 2007;408(1): 51-9.

85. Gatlin JC, Estrada-Bernal A, Sanford SD, Pfenninger KH. Myristoylated, alanine-rich C-kinase substrate phosphorylation regulates growth cone adhesion and pathfinding. Mol Biol Cell. 2006;17(12):5115-30.

86. Shiraishi M, Tanabe A, Saito N, Sasaki Y. Unphosphorylated MARCKS is involved in neurite initiation induced by insulin-like growth factor-l in SHSY5Y cells. J Cell Physiol. 2006;209(3):1029-38.

87. Yu D, Makkar G, Dong T, Strickland DK, Sarkar R, Monahan TS. MARCKS signaling differentially regulates vascular smooth muscle and endothelial cell proliferation through a KIS-, p27kip1- dependent mechanism. PLoS One. 2015;10(11):e0141397.

88. Eckert RE, Neuder LE, Park J, Adler KB, Jones SL. Myristoylated alanine-rich Ckinase substrate (MARCKS) protein regulation of human neutrophil migration. Am J Respir Cell Mol Biol. 2010;42(5):586-94.

89. Chen $X$, Rotenberg SA. PhosphoMARCKS drives motility of mouse melanoma cells. Cell Signal. 2010;22(7):1097-103.

90. Green TD, Park J, Yin Q, Fang S, Crews AL, Jones SL, Adler KB. Directed migration of mouse macrophages in vitro involves myristoylated alaninerich C-kinase substrate (MARCKS) protein. J Leukoc Biol. 2012;92(3):633-9.

91. Sheats MK, Sung EJ, Adler KB, Jones SL. In vitro neutrophil migration requires protein kinase C-Delta (delta-PKC)-mediated Myristoylated alaninerich C-kinase substrate (MARCKS) phosphorylation. Inflammation. 2015;38(3): 1126-41.

92. Yu D, Makkar G, Strickland DK, Blanpied TA, Stumpo DJ, Blackshear PJ, Sarkar R, Monahan TS. Myristoylated alanine-rich protein kinase substrate (MARCKS) regulates small GTPase Rac1 and Cdc42 activity and is a critical mediator of vascular smooth muscle cell migration in intimal hyperplasia formation. J Am Heart Assoc. 2015;4(10):e002255.

93. Scarlett CO, Blackshear PJ. Neuroanatomical development in the absence of PKC phosphorylation of the myristoylated alanine-rich C-kinase substrate (MARCKS) protein. Brain Res Dev Brain Res. 2003;144(1):25-42.

94. Swierczynski SL, Siddhanti SR, Tuttle JS, Blackshear PJ. Nonmyristoylated MARCKS complements some but not all of the developmental defects associated with MARCKS deficiency in mice. Dev Biol. 1996;179(1):135-47.

95. Kim HS, Swierczynski SL, Tuttle JS, Lai WS, Blackshear PJ. Transgenic complementation of MARCKS deficiency with a nonmyristoylatable, pseudophosphorylated form of MARCKS: evidence for simultaneous positive and dominant-negative effects on central nervous system development. Dev Biol. 1998;200(2):146-57

96. Disatnik MH, Boutet SC, Pacio W, Chan AY, Ross LB, Lee CH, Rando TA. The bi-directional translocation of MARCKS between membrane and cytosol regulates integrin-mediated muscle cell spreading. J Cell Sci. 2004;117 (Pt 19):4469-79.

97. Sheats MK, Pescosolido KC, Hefner EM, Sung EJ, Adler KB, Jones SL. Myristoylated alanine rich C kinase substrate (MARCKS) is essential to beta2-integrin dependent responses of equine neutrophils. Vet Immunol Immunopathol. 2014;160(3-4):167-76. 
98. Shi Y, Sullivan SK, Pitterle DM, Kennington EA, Graff JM, Blackshear PJ. Mechanisms of MARCKS gene activation during Xenopus development. J Biol Chem. 1997;272(46):29290-300.

99. Zhao H, Cao Y, Grunz H. Isolation and characterization of a Xenopus gene (XMLP) encoding a MARCKS-like protein. Int J Dev Biol. 2001;45(7):817-26.

100. Blackshear PJ, Lai WS, Tuttle JS, Stumpo DJ, Kennington E, Nairn AC, Sulik KK. Developmental expression of MARCKS and protein kinase $C$ in mice in relation to the exencephaly resulting from MARCKS deficiency. Brain Res Dev Brain Res. 1996;96(1-2):62-75.

101. Zolessi FR, Arruti C. Sustained phosphorylation of MARCKS in differentiating neurogenic regions during chick embryo development. Brain Res Dev Brain Res. 2001;130(2):257-67.

102. Ruiz-Perera LM, Arruti C, Zolessi FR. Early phosphorylation of MARCKS at Ser25 in migrating precursor cells and differentiating peripheral neurons. Neurosci Lett. 2013;544:5-9.

103. McNamara RK, Wees EA, Lenox RH. Differential subcellular redistribution of protein kinase $\mathrm{C}$ isozymes in the rat hippocampus induced by kainic acid. J Neurochem. 1999;72(4):1735-43.

104. Wees E, McNamara R, Meberg P, Kuhn T, Lenox R. The PKC substrate MARCKS is enriched in neuronal growth cones and developmentally regulated in the rat hippocampus. Soc Neurosci Abs. 1998;24:537.

105. Calabrese B, Halpain S. Essential role for the PKC target MARCKS in maintaining dendritic spine morphology. Neuron. 2005:48(1):77-90.

106. Wu M, Chen DF, Sasaoka T, Tonegawa S. Neural tube defects and abnormal brain development in F52-deficient mice. Proc Natl Acad Sci. 1996;93(5):2110-5.

107. Chen J, Chang S, Duncan SA, Okano HJ, Fishell G, Aderem A. Disruption of the MacMARCKS gene prevents cranial neural tube closure and results in anencephaly. Proc Natl Acad Sci. 1996;93(13):6275-9.

108. Fleming A, Copp AJ. A genetic risk factor for mouse neural tube defects: defining the embryonic basis. Hum Mol Genet. 2000;9(4):575-81.

109. Kim SS, Kim JH, Lee SH, Chung SS, Bang OS, Park D, Chung CH. Involvement of protein phosphatase-1-mediated MARCKS translocation in myogenic differentiation of embryonic muscle cells. J Cell Sci. 2002;115(Pt 12):2465-73.

110. Garrett AM, Schreiner D, Lobas MA, Weiner JA. y-protocadherins control cortical dendrite arborization by regulating the activity of a FAK/PKC/MARCKS signaling pathway. Neuron. 2012;74(2):269-76.

111. Sosa L, Malter JS, Hu J, Bustos Plonka F, Oksdath M, Nieto Guil AF, Quiroga S, Pfenninger KH. Protein interacting with NIMA (never in mitosis a)-1 regulates axonal growth cone adhesion and spreading through myristoylated alaninerich C kinase substrate isomerization. J Neurochem. 2016;137(5):744-55.

112. Yamaguchi $H$, Shiraishi M, Fukami $K$, Tanabe A, Ikeda-Matsuo $Y$, Naito $Y$, Sasaki Y. MARCKS regulates lamellipodia formation induced by IGF-I via association with PIP2 and beta-actin at membrane microdomains. J Cell Physiol. 2009;220(3):748-55.

113. Cordero DR, Brugmann S, Chu Y, Bajpai R, Jame M, Helms JA. Cranial neural crest cells on the move: their roles in craniofacial development. Am J Med Genet A. 2011;155A(2):270-9.

114. Martik ML, Bronner ME. Regulatory logic underlying diversification of the neural crest. Trends Genet. 2017;33(10):715-27.

115. Rochlin K, Yu S, Roy S, Baylies MK. Myoblast fusion: when it takes more to make one. Dev Biol. 2010;341(1):66-83.

116. Kalwa H, Sartoretto JL, Sartoretto SM, Michel T. Angiotensin-II and MARCKS: a hydrogen peroxide- and RAC1-dependent signaling pathway in vascular endothelium. J Biol Chem. 2012;287(34):29147-58.

117. Trovo L, Ahmed T, Callaerts-Vegh Z, Buzzi A, Bagni C, Chuah M, Vandendriessche T, D'Hooge R, Balschun D, Dotti CG. Low hippocampal $\mathrm{PI}(4,5) \mathrm{P}(2)$ contributes to reduced cognition in old mice as a result of loss of MARCKS. Nat Neurosci. 2013;16(4):449-55.

118. Finlayson AE, Freeman KW. A cell motility screen reveals role for MARCKSrelated protein in adherens junction formation and tumorigenesis. PLOS One. 2009;4(11):e7833.

119. Zhang Y, Bo X, Schoepfer R, Holtmaat AJ, Verhaagen J, Emson PC, Lieberman AR, Anderson PN. Growth-associated protein GAP-43 and L1 act synergistically to promote regenerative growth of Purkinje cell axons in vivo. Proc Natl Acad Sci U S A. 2005;102(41):14883-8.

120. Mason MR, Lieberman A, Grenningloh G, Anderson P. Transcriptional upregulation of SCG10 and CAP-23 is correlated with regeneration of the axons of peripheral and central neurons in vivo. Mol Cell Neurosci. 2002;20(4): 595-615.

121. Makwana M, Raivich G. Molecular mechanisms in successful peripheral regeneration. FEBS J. 2005;272(11):2628-38.
122. Verhaagen J, Van Hooff C, Edwards P, De Graan P, Oestreicher A, Schotman $P$, Jennekens F, Gispen W. The kinase C substrate protein B-50 and axonal regeneration. Brain Res Bull. 1986;17(6):737-41.

123. Szpara ML, Vranizan K, Tai YC, Goodman CS, Speed TP, Ngai J. Analysis of gene expression during neurite outgrowth and regeneration. BMC Neurosci. 2007;8(1):100.

124. Frey D, Laux T, Xu L, Schneider C, Caroni P. Shared and unique roles of CAP23 and GAP43 in actin regulation, neurite outgrowth, and anatomical plasticity. J Cell Biol. 2000;149(7):1443-54.

125. Caroni P, Aigner L, Schneider C. Intrinsic neuronal determinants locally regulate extrasynaptic and synaptic growth at the adult neuromuscular junction. J Cell Biol. 1997;136(3):679-92.

126. Carmichael ST, Archibeque I, Luke L, Nolan T, Momiy J, Li S. Growthassociated gene expression after stroke: evidence for a growth-promoting region in peri-infarct cortex. Exp Neurol. 2005;193(2):291-311.

127. Van der Zee C, Nielander HB, Vos JP, da Silva SL, Verhaagen J, Oestreicher AB, Schrama LH, Schotman P, Gispen WH. Expression of growth-associated protein B-50 (GAP43) in dorsal root ganglia and sciatic nerve during regenerative sprouting. J Neurosci. 1989;9(10): 3505-12.

128. Pellier-Monnin V, Astic L, Bichet S, Riederer BM, Grenningloh G. Expression of SCG10 and stathmin proteins in the rat olfactory system during development and axonal regeneration. J Comp Neurol. 2001; 433(2):239-54.

129. Doster SK, Lozano AM, Aguayo AJ, Willard MB. Expression of the growthassociated protein GAP-43 in adult rat retinal ganglion cells following axon injury. Neuron. 1991;6(4):635-47.

130. Mason M, Lieberman A, Anderson P. Corticospinal neurons up-regulate a range of growth-associated genes following intracortical, but not spinal, axotomy. Eur J Neurosci. 2003;18(4):789-802.

131. Bomze HM, Bulsara KR, Iskandar BJ, Caroni P, Skene JP. Spinal axon regeneration evoked by replacing two growth cone proteins in adult neurons. Nat Neurosci. 2001;4(1):38

132. Aigner L, Arber S, Kapfhammer JP, Laux T, Schneider C, Botteri F, Brenner $H R$, Caroni P. Overexpression of the neural growth-associated protein GAP43 induces nerve sprouting in the adult nervous system of transgenic mice. Cell. 1995;83(2):269-78.

133. Buffo A, Holtmaat AJ, Savio T, Verbeek JS, Oberdick J, Oestreicher AB, Gispen WH, Verhaagen J, Rossi F, Strata P. Targeted overexpression of the neurite growth-associated protein B-50/GAP-43 in cerebellar Purkinje cells induces sprouting after axotomy but not axon regeneration into growthpermissive transplants. J Neurosci. 1997;17(22):8778-91.

134. Allegra Mascaro AL, Cesare P, Sacconi L, Grasselli G, Mandolesi G, Maco B, Knott GW, Huang L, De Paola V, Strata P, Pavone FS. In vivo single branch axotomy induces GAP-43-dependent sprouting and synaptic remodeling in cerebellar cortex. Proc Natl Acad Sci U S A. 2013;110(26):10824-9.

135. Veldman MB, Bemben MA, Thompson RC, Goldman D. Gene expression analysis of zebrafish retinal ganglion cells during optic nerve regeneration identifies KLF6a and KLF7a as important regulators of axon regeneration. Dev Biol. 2007;312(2):596-612.

136. Sousounis K, Bhavsar R, Looso M, Kruger M, Beebe J, Braun T, Tsonis PA. Molecular signatures that correlate with induction of lens regeneration in newts: lessons from proteomic analysis. Hum Genomics. 2014;8:22.

137. Bock-Marquette I, Shrivastava S, Pipes GT, Thatcher JE, Blystone A, Shelton JM, Galindo CL, Melegh B, Srivastava D, Olson EN. Thymosin $\beta 4$ mediated PKC activation is essential to initiate the embryonic coronary developmental program and epicardial progenitor cell activation in adult mice in vivo. J Mol Cell Cardiol. 2009;46(5):728-38.

138. Gurtner GC, Callaghan MJ, Longaker MT. Progress and potential for regenerative medicine. Annu Rev Med. 2007;58:299-312.

139. Gurtner GC, Werner S, Barrandon Y, Longaker MT. Wound repair and regeneration. Nature. 2008;453(7193):314.

140. Friedl P, Gilmour D. Collective cell migration in morphogenesis, regeneration and cancer. Nat Rev Mol Cell Biol. 2009;10(7):445.

141. Ridley AJ, Schwartz MA, Burridge K, Firtel RA, Ginsberg MH, Borisy G, Parsons JT, Horwitz AR. Cell migration: integrating signals from front to back. Science. 2003:302(5651):1704-9.

142. Kawakami Y, Esteban CR, Raya M, Kawakami H, Martí M, Dubova I, Belmonte $\mathrm{JCl}$. Wnt/B-catenin signaling regulates vertebrate limb regeneration. Genes Dev. 2006;20(23):3232-7. 
143. Donnelly DJ, Popovich PG. Inflammation and its role in neuroprotection, axonal regeneration and functional recovery after spinal cord injury. Exp Neurol. 2008;209(2):378-88.

144. Mescher AL, Neff AW, King MW. Inflammation and immunity in organ regeneration. Dev. Comp. Immunol. 2017;66:98-110.

145. Eming SA, Wynn TA, Martin P. Inflammation and metabolism in tissue repair and regeneration. Science. 2017;356(6342):1026-30.

146. Guo Q, Li S, Liang Y, Zhang Y, Zhang J, Wen C, Lin S, Wang H, Su B. Effects of C3 deficiency on inflammation and regeneration following spinal cord injury in mice. Neurosci Lett. 2010;485(1):32-6.

147. Karin M, Clevers $H$. Reparative inflammation takes charge of tissue regeneration. Nature. 2016;529(7586):307.

148. Silburt J, Lipsman N, Aubert I. Disrupting the blood-brain barrier with focused ultrasound: perspectives on inflammation and regeneration. Proc Natl Acad Sci. 2017:114(33):E6735-6.

149. Cooper PR, Takahashi Y, Graham LW, Simon S, Imazato S, Smith AJ. Inflammation-regeneration interplay in the dentine-pulp complex. J Dent. 2010;38(9):687-97.

150. Forn-Cuní G, Varela M, Pereiro P, Novoa B, Figueras A. Conserved gene regulation during acute inflammation between zebrafish and mammals. Sci Rep. 2017;7:41905

151. Godwin JW, Pinto AR, Rosenthal NA. Macrophages are required for adult salamander limb regeneration. Proc Natl Acad Sci. 2013;110(23):9415-20.

152. Tanaka EM. The molecular and cellular choreography of appendage regeneration. Cell. 2016;165(7):1598-608.

153. Li J, Aderem A. MacMARCKS, a novel member of the MARCKS family of protein kinase C substrates. Cell. 1992;70(5):791-801.

154. Carballo E, Pitterle DM, Stumpo DJ, Sperling RT, Blackshear PJ. Phagocytic and macropinocytic activity in MARCKS-deficient macrophages and fibroblasts. Am J Phys Cell Phys. 1999;277(1):C163-73.

155. Zhou X, Li J. Macrophage-enriched myristoylated alanine-rich C kinase substrate and its phosphorylation is required for the phorbol ester-stimulated diffusion of $\beta 2$ integrin molecules. J Biol Chem. 2000;275(26):20217-22.

156. Chun K-R, Bae EM, Kim J-K, Suk K, Lee W-H. Suppression of the lipopolysaccharide-induced expression of MARCKS-related protein (MRP) affects transmigration in activated RAW264. 7 cells. Cell Immunol. 2009;256(1):92-8

157. Li J, D'annibale-Tolhurst MA, Adler KB, Fang S, Yin Q, Birkenheuer AJ, Levy MG, Jones SL, Sung EJ, Hawkins EC, Yoder JA, Nordone SK. A myristoylated alanine-rich $C$ kinase substrate-related peptide suppresses cytokine mRNA and protein expression in LPS-activated canine neutrophils. Am J Respir Cell Mol Biol. 2013;48(3):314-21.

158. Lee SM, Suk K, Lee WH. Myristoylated alanine-rich C kinase substrate (MARCKS) regulates the expression of proinflammatory cytokines in macrophages through activation of p38/JNK MAPK and NF-kappaB. Cell Immunol. 2015;296(2):115-21.

159. Eun SY, Kim EH, Kang KS, Kim HJ, Jo SA, Kim SJ, Jo SH, Kim SJ, Blackshear PJ, Kim J. Cell type-specific upregulation of myristoylated alanine-rich $C$ kinase substrate and protein kinase C-alpha, -beta I, -beta II, and -delta in microglia following kainic acid-induced seizures. Exp Mol Med. 2006;38(3):310-9.

160. Shokouhi BN, Wong BZ, Siddiqui S, Lieberman AR, Campbell G, Tohyama K, Anderson PN. Microglial responses around intrinsic CNS neurons are correlated with axonal regeneration. BMC Neurosci. 2010:11(1):13.

161. Kitayama M, Ueno M, Itakura T, Yamashita T. Activated microglia inhibit axonal growth through RGMa. PLoS One. 2011:6(9):e25234.

162. Hasegawa H, Nakai M, Tanimukai S, Taniguchi T, Terashima A, Kawamata T, Fukunaga K, Miyamoto E, Misaki K, Mukai H, Tanaka C. Microglial signaling by amyloid beta protein through mitogen-activated protein kinase mediating phosphorylation of MARCKS. Neuroreport. 2001;12(11):2567-71.

163. Topham MK, Bunting M, Zimmerman GA, Mclntyre TM, Blackshear PJ, Prescott SM. Protein kinase $C$ regulates the nuclear localization of diacylglycerol kinase-乙. Nature. 1998;394(6694):697.

164. Luo B, Prescott SM, Topham MK. Protein kinase Ca phosphorylates and negatively regulates diacylglycerol kinase $\zeta$. J Biol Chem. 2003; 278(41):39542-7.

165. Los AP, de Widt J, Topham MK, van Blitterswijk WJ, Divecha N. Protein kinase C inhibits binding of diacylglycerol kinase- $\zeta$ to the retinoblastoma protein. Biochimica et Biophysica Acta (BBA)-molecular. Cell Res. 2007;1773(3):352-7.

166. Tanaka EM, Gann AA, Gates PB, Brockes JP. Newt myotubes reenter the cell cycle by phosphorylation of the retinoblastoma protein. J Cell Biol. 1997; 136(1):155-65
167. Sage J, Miller AL, Pérez-Mancera PA, Wysocki JM, Jacks T. Acute mutation of retinoblastoma gene function is sufficient for cell cycle re-entry. Nature. 2003;424(6945):223.

168. Weber T, Corbett MK, Chow LM, Valentine MB, Baker SJ, Zuo J. Rapid cellcycle reentry and cell death after acute inactivation of the retinoblastoma gene product in postnatal cochlear hair cells. Proc Natl Acad Sci. 2008; 105(2):781-5.

169. Rohrbach TD, Shah N, Jackson WP, Feeney EV, Scanlon S, Gish R, Khodadadi R, Hyde SO, Hicks PH, Anderson JC, Jarboe JS, Willey CD. The effector domain of MARCKS is a nuclear localization signal that regulates cellular PIP2 levels and nuclear PIP2 localization. PLoS One. 2015:10(10):e0140870.

170. Wang L, Watson DG, Lenox RH. Myristoylation alters retinoic acid-induced down-regulation of MARCKS in immortalized hippocampal cells. Biochem Biophys Res Commun. 2000;276(1):183-8.

171. Maden M. Retinoic acid in the development, regeneration and maintenance of the nervous system. Nat Rev Neurosci. 2007;8(10):755.

172. Lefebvre PP, Malgrange B, Staecker H, Moonen G, Van De Water TR. Retinoic acid stimulates regeneration of mammalian auditory hair cells. Science. 1993;260(5108):692-5.

173. Maden M. Vitamin a and pattern formation in the regenerating limb. Nature. 1982;295(5851):672.

174. Maden M, Hind M. Retinoic acid, a regeneration-inducing molecule. Dev Dyn. 2003;226(2):237-44

175. White JA, Boffa MB, Jones B, Petkovich M. A zebrafish retinoic acid receptor expressed in the regenerating caudal fin. Development. 1994;120(7):1861-72.

176. Wehner $D$, Weidinger $G$. Signaling networks organizing regenerative growth of the zebrafish fin. Trends Genet. 2015;31(6):336-43.

177. Chang JT, Lehtinen MK, Sive H. Zebrafish cerebrospinal fluid mediates cell survival through a retinoid signaling pathway. Dev. Neurobiol. 2016;76(1):75-92.

178. Singer M, Martin LD, Vargaftig BB, Park J, Gruber AD, Li Y, Adler KB. A MARCKS-related peptide blocks mucus hypersecretion in a mouse model of asthma. Nat Med. 2004;10(2):193.

\section{Ready to submit your research? Choose BMC and benefit from:}

- fast, convenient online submission

- thorough peer review by experienced researchers in your field

- rapid publication on acceptance

- support for research data, including large and complex data types

- gold Open Access which fosters wider collaboration and increased citations

- maximum visibility for your research: over $100 \mathrm{M}$ website views per year

At BMC, research is always in progress.

Learn more biomedcentral.com/submissions 